\title{
DEMYSTIFICATION OF THE MYTH OF FREEDOM IN THE CHARACTERIZATION OF CHRISTOPHER MCCANDLESS IN KRAKAUER'S INTO THE WILD
}

\author{
Ni Komang Arie Suwastini ${ }^{1}$, Gusti Ayu Putu Suprianti ${ }^{2}$, Nyoman Trijaya Suparyanta ${ }^{3}$ \\ Ganesha University of Education, Jalan Raya Sesetan No.196, Denpasar, Bali 80223 \\ arie.suwastini80@gmail.com¹, gap.suprianti@undiksha.ac.id², nyoman603@gmail.com³
}

\begin{abstract}
While Krakauer's Into The Wild depicts McCandless' flee from society to live in the wild, many reviews argue that McCandless was not really a kind of person who finds freedom in nature. The present study will investigate further the surface characterizations of McCandless as freedom chaser with the plot development to fill the gap between McCandless' characterizations and the myth of freedom that he chases. By applying Barthes' mythology, the study reveals that McCandless was described as an adventurer, immaterialist, and loner. However, the plot development reveals that as a person who sought an adventure in nature, McCandless would deal with water, but knowing that he had fear of water, it is contradictive with his characterization as an adventurer. As a person who rejected capitalism and materialist society, he was found working at McDonald's for having money in which both McDonalds and money are symbols of capitalism and materialistic society. As a person who spent his time mostly alone and intended to be alone in Alaska, he was a lonely person after all. Thus these contradictions demystify the myth of freedom that McCandless chases.
\end{abstract}

Key Words: Into The Wild, freedom, myth, characterizations, demystification

DOI: 10.15642/NOBEL.2019.10.1.01-14

The death of Chris McCandless in a bus became viral. This also becomes one of the reasons of Krakauer creates Into the Wild. The essay that Krakauer wrote about McCandless had resulted in the positive comments from the reader which led to the making of the book. Into the Wild tells about a young man, namely, Christopher Johnson McCandless who flees from his society to live alone in Alaska Wilderness. From the beginning of the story, McCandless showed any signs of disliking his old society which was full of materialistic people. He rejected the new car that his parents gave him, telling them that he already had the best car. He even gave Jim Gallien all of his money and watch and told him that he did not need that. After donating all of the money he had for his study to a charity, he decided to leave home adopting a new name: Alexander Super-tramp.

Chris McCandless was depicted as an adventurer, immaterialistic person, and a loner. He had done several adventures during his journey to Alaska, like camping in a tent and getting a free lift by hitchhiking in order to achieve his destination. He was not a materialistic person since he had rejected the car and left his upper-middle-class society to live his new life 
as a vagabond. Mostly, he spent his time alone and stayed out of people for a long time. When he met Franz and refused Franz' offer to be his grandson, McCandless felt relieved that he could evade the emotional feeling resulted in a long-term relationship. This signifies that he wanted to live alone without society. Connecting these surface characterizations with how McCandless left his society, these connote Chris McCandless as a free spirit person and a freedom chaser.

Chris McCandless was depicted as an adventurer, immaterialistic person, and a loner. He had done several adventures during his journey to Alaska, like camping in a tent and getting a free lift by hitchhiking in order to achieve his destination. He was not a materialistic person since he had rejected the car and left his upper-middle-class society to live his new life as a vagabond. Mostly, he spent his time alone and stayed out of people for a long time. When he met Franz and refused Franz' offer to be his grandson, McCandless felt relieved that he could evade the emotional feeling resulted in a long-term relationship. This signifies that he wanted to live alone without society. Connecting these surface characterizations with how McCandless left his society, these connote McCandless as a free spirit person and a freedom chaser.

While the myth of freedom is constructed from the surface characterizations of McCandless, the plot development of Into the Wild reveals that in the end, McCandless felt lonely and even wanted to go back to civilization. This creates questions: Was freedom what McCandless intended to find? Were there any reasons McCandless hated his society and decided to leave home? Thus, the surface characterizations and the characterizations revealed in the plot development of McCandless' story create a gap between McCandless who was a freedom chaser and McCandless as a lonely man. The present study will investigate how these characterizations deny the signifiers of freedom and demystify the myth of freedom that McCandless chases.

The research design used in this study was a qualitative study in the form of interpreting the qualitative design. According to Prior (2008), interpreting qualitative method is a method in which the researcher construes meaning from research findings and use the researcher's assumption/interpretation to provide a context to help the readers understand the result of the study. This research used textual analysis as the research method. According to Lockyer (2008) in Given (2008), textual analysis is a method to examine both the content and meaning of texts or their structure and discourse as accurate as possible. The data of this research were the signifiers which show the characterizations which signify the myth of freedom and the characterizations which demystify the myth of freedom from those 
signifiers. After the data were gathered, they were analyzed by using Semiotics theory from Roland Barthes.

\section{DISCUSSIONS OF MAIN THEMES}

\section{Myth of freedom}

The surface characterizations of McCandless signify the myth of freedom. Those characterizations are an adventurer, immaterialist, and a loner. Stated below are the characterizations of McCandless which signify the myth of freedom, alongside with the analysis.

\section{Adventurer}

The first characterization which signifies the myth of freedom is an adventurer. This characterization is shown in sequences: 1a, 3a, 4d, 5d, 6a, 7a, 8a, 8b, 8d, 11a, and 12d. Sequence 1a tells about the meeting with Jim Gallien, a truck driver who gave McCandless a ride just before he disappeared into the wild. McCandless met Gallien when he was hitchhiking in Fairbanks, Alaska. Sequence 3a tells about the meeting with Wayne Westerberg. Westerberg took McCandless to his place in Chartage, giving him a place to stay and a job. Sequence 4d tells about the disappearance of McCandless from his family's sight. This sequence tells about McCandless' past just before he left his home and changed his name into Alexandre Super-Tramp. Sequence 5d tells about the journey in Lake Mead, where McCandless got a ride from the passing boaters. Sequence 6a tells about meeting with Jan Burres and Bob. McCandless met this couple when he was picking the berries. McCandless had stayed with them until Orick Beach, where he decided to continue his journey. Sequence 7a tells about the ticketing activity from McCandless. McCandless tried to have an adventure in Willow Creek, where he was caught because of ticketing. Sequence 8a tells about McCandless' journey to Mexico through Colorado River. Following the Colorado River, McCandless had paddled his canoe until he reached Mexico. Sequence 8b tells about the help from duck hunter whom he met when he was in Mexico. Sequence 8d tells about immigration office (no ID). This sequence tells about McCandless who was caught by the immigration office when he entered the USA because he did not bring any ID. Sequence 11a tells about the meeting with Ronald Franz. This sequence tells about McCandless' journey in Anza Borrego and met Ronald Franz who gave him a place to stay. Sequence 12d tells about the departure to Alaska. This sequence tells about McCandless departure to Alaska after he said goodbye to Westerberg. 
As McCandless decided to leave his home to have an adventure to Alaska, he can be characterized as an adventurer. During his trip to Alaska, McCandless had done several adventures. The evidence of his adventures is his appearances in those places. He even was depicted as an adventurer from the opening of the story which is in sequence 1a. From the opening of the story, McCandless had appeared in front of the truck driver name Gallien. McCandless got a free ride from Gallien, and he told Gallien about his intention to live off the land for a few months, "He explained that he wanted a ride as far as the edge of Denali National Park, where he intended to walk deep into the bush and "live off the land for a few months." (Krakauer, 1995: 5).

From the part of the story above, what denoted here is McCandless' intention to have a ride as far as the edge of Denali National Park to live off the land for a few months. The line "He explained that he wanted a ride as far as the edge of Denali National Park" signifies that McCandless sought for adventure. McCandless wanted to have an adventure in Denali National Park. Seeking for adventure signifies the adventurer characterization. Relating to his goal, McCandless wanted to live alone in Alaska and he could achieve that by doing an adventure. Having an odyssey to Alaska in order to live alone there and be free from his society becomes the signifier of the myth of freedom.

This myth is also supported by the setting where McCandless and Gallien met, which is Fairbanks, Alaska. McCandless decided to have an odyssey to Alaska in order to find freedom from society. He decided to live there with nature. The odyssey becomes the signifier of finding freedom. Thus, the setting of this passage signifies the myth of freedom.

\section{Immaterialist}

The second characterization which signifies the myth of freedom is immaterialist. Immaterialist means not materialistic. The word "materialistic" means excessively concerned with material possessions or money-oriented. This characterization is shown in the sequence 1c and 4c. Sequence 1c tells about the disappearance of McCandless into the wild. In sequence 1c, McCandless insisted to give Gallien his money, which was 85 cents; his comb; and his watch, but Gallien insisted not to take them. McCandless then told Gallien that if Gallien did not take them, he would throw them away. The way McCandless gave Gallien his money, watch and comb signify the non-materialistic characterization. Sequence 4c tells about the family meeting. In sequence $\mathbf{4 c}$, McCandless had rejected the offer from his family about the new car. He told them that he already had the best car. This signifies McCandless who was not materialistic. 
The intention to live alone in Alaska was caused by McCandless' disliking towards his old world which was full of materialistic people. The part of the story in sequence $\mathbf{4 c}$ tells that McCandless had rejected the offer from his family about the new car. He told them that he already had the best car. This can be seen from the passage: "Indeed, McCandless had only recently upbraided Walt and Billie for expressing their desire to buy him a new car as a graduation present and offering to pay for law school if there wasn't enough money left in his college fund to cover it. (Krakauer, 1995: 16)

The part of the story above gives the information that he rejected the offer of a new car from his family. The word "upbraided" signifies the rejection towards the new car. He rejected the new car from his family because he already had a car. McCandless had upbraided his parents because they offer him a new car as a present for his graduation. He already had a car so that was why he rejected the offer. This shows any disliking towards the way his parents thought about money. The word upbraided connotes the rejection towards materialistic society.

Another evidence of immaterialist characterization happens when McCandless met Gallien. In the story, McCandless insisted to give Gallien his money, which was 85 cents, his comb, and his watch, but Gallien insisted not to take them. McCandless then told Gallien that if Gallien did not take them, he would throw them away, "Alex insisted on giving Gallien his watch, his comb, and what he said was all his money: eighty-five cents in loose change...... [sic] "If you don't take it, I'm going to throw it away," Alex cheerfully retorted. (Krakauer, 1995:7).

The line "If you don't take it, I'm going to throw it away," signifies that McCandless was immaterialist. The way McCandless gave Gallien his money, watch and comb signify the immaterialist characterization. McCandless did not want to concern with the material or money that he had. He even told Gallien that he would throw his money, comb and watch away if Gallien did not take them. The way McCandless thought about his old society, which was materialistic, signifies the reason McCandless did his journey to Alaska. McCandless wanted to be free from the society which was materialistic. The way McCandless wanted to be free from the materialistic society signifies the myth of freedom

\section{Loner}

During his adventure to Alaska, McCandless met several people, although he mostly spent his time alone. This signifies the characterization of a loner. This characterization is shown in sequences 11c, 12b, 13a, 14c, and 16c. Sequence 11c tells about Franz's thoughts on McCandless. Franz thought that McCandless was an interesting man that made him wanted to 
adopt him as his grandson. The sequence 12b tells about the meeting with Borah. Borah stated that McCandless was a little bit shy and seemed hard to be around people at first meeting. She thought that it might be because McCandless spent so much time by himself. Sequence 13a tells about Carine's thought on McCandless. Carine stated that when McCandless was young, he was very occupied to himself. He did not seem to need a toy or friends. He could be alone without being lonely. Sequence 14c tells about the drive to Fairbanks. There is a part of the story in this sequence where McCandless told Stuckey that he did not want to see a single person, airplanes, or any signs of civilization. He wanted to prove himself that he could make it on his own. Sequence 16c tells about McCandless' declaration of independence. He wrote that he walked for two years on the road with no phone no pool, and no cigarettes. He was no longer poisoned by civilization. He walks alone upon the land to become lost into the wild. Thus, this characterization is mainly about McCandless who wanted to live alone in Alaska with no sign of civilization.

When McCandless met Ronald Franz in sequence 11c, he had stayed with Franz for several days and then Franz asked McCandless whether he wanted to be his grandson, but McCandless refused Franz' request. McCandless felt relieved because he could evade the emotional baggage made in every relationship with the people he met, "So I asked Alex if I could adopt him, if he would be my grandson." McCandless, uncomfortable with the request, dodged the question...[sic $\}$ he was relieved as well-relieved that he had again evaded the impending threat of human intimacy, of friendship, and all the messy emotional baggage that comes with it." (Krakauer, 1995:37).

The quote above tells about McCandless' rejection of Franz' offer. The line "McCandless, uncomfortable with the request" signifies that he did not want to make a further relationship with Franz. He refused the offer to be Franz's grandson. Based on the passage above, McCandless also felt relieved that he could evade the intimacy and the emotional baggage resulted from it. The word "relieved" signifies that McCandless could be alone. If he made a further relationship with people, he could not live alone in Alaska. His decision was to live alone in the Alaska wilderness. He could not achieve that if he made a further relationship with people. This situation signifies loner characterization.

The loner characterization signifies independent life. By living alone without any society, McCandless would have his independent life because he did not rely much on society. McCandless decided to have a journey to Alaska in order to achieve freedom from society. Having a loner characterization builds a connotation of independent. The odyssey to Alaska signifies freedom from society. The odyssey to Alaska and the independent life which 
McCandless build connote the freedom from society. In conclusion, loner characterization signifies the myth of freedom.

\section{Demystification of the myth of freedom}

The main objective of this research is to demystify the myth of freedom from Chris McCandless' character. From the plot development Chris McCandless' story in Into The Wild, there are three characterizations which are against the myth of freedom, they are fear of water, persistent fear to depart from capitalist consumption and endless suffering from loneliness.

\section{Fear of water}

Water is an integral part of nature. As a person who wanted to live in nature, McCandless will deal with water. Thus, McCandless should not have any fear of water. The first characterization which denies the myth of freedom is fear of water. This characterization is shown in sequence 1b and 18c. The signifier of afraid of water in sequence 1c is when McCandless looked down at Nenana River and he realized that he was afraid of water. The signifier of afraid of water in sequence $\mathbf{1 8 c}$ is McCandless could not swim to Teklanika River because he was afraid of water.

From the plot development, at first, McCandless did not show any fear of water until he reached Mexico where he faced a storm which almost killed him. Facing a storm in Mexico becomes the beginning of his fear of water. In sequence 1b, McCandless met Jim Gallien, a truck driver who gave him a ride. To the truck driver, McCandless had claimed that he was afraid of water, "As the truck lurched over a bridge across the Nenana River, Alex looked down at the swift current and remarked that he was afraid of the water. "A year ago down in Mexico," he told Gallien, "I was out on the ocean in a canoe, and I almost drowned when a storm came up." (Krakauer, 1995:6)"

From the part of the story above, what is denoted here is the fear of water characterization. From the first line of the part of the story above, it is known that, by looking down at Nenana River, McCandless shows any gesture that he wanted to make sure about the condition of the water. By knowing that the water of Nenana River moved fast, he mentioned to Gallien that he was afraid of water. McCandless also mentioned that a year ago in Mexico while canoeing, he faced a storm that almost drowned him. This bad experience made him afraid of water.

From the part of the story above, the location of McCandless should be near Nenana River, because he easily looked down at the river. This river is located in Alaska. By 
knowing that McCandless' intention was to live alone in Alaska, there should be some big rivers in Alaska, for example, Teklanika River. Due to his fear of the water, McCandless could not move further if he faced the big rivers to continue his adventure. This becomes contradictory that as a person who sought an adventure in nature, McCandless was afraid of water which is part of nature. Thus, this contradiction denies the idea of an adventurer.

McCandless' fear of water connotes that he could not survive his life alone in the Alaska wilderness. While he was in Alaska, he should face a lot of big rivers. He will put his life in danger if he is trapped in a situation where he could not cross the river. Further investigation results that the part of the story below denotes the condition where McCandless could not move further because he could not cross the river, "McCandless was a weak swimmer and had confessed to several people that he was, in fact, afraid of the water. Attempting to swim the numbingly cold torrent or even to paddle some sort of improvised raft across seemed too risky to consider." (Krakauer, 1995:117).

The information that is denoted from the part of the story above is the fear of water characterization and a weak swimmer. This can be seen from the first line of the quote. Swimming ability is essential especially for those who deal a lot with nature. Being signified as a weak swimmer reveals that McCandless was lack of surviving ability. As an adventurer, having a lack of swimming ability will put McCandless' life in danger and limit McCandless field of adventure. He could not continue his trip if he faces the big rivers which require him to swim across. This lack of swimming ability is also supported with the fear towards the water, makes it harder for him to continue his adventurer, thus becomes a contradiction with his characterization as an adventurer.

Thus, based on the investigation above, being afraid of water connotes McCandless' unavailability to live in Alaska considering that Alaska has lots of big rivers. For a person who sought adventure in nature, McCandless must deal with water a lot, since water is an integral part of nature. Not only having fear of water, but he also had a lack of swimming ability which is necessary for him to survive his life. The fear of water becomes a contradiction towards an adventure characterization as the signifier of the myth of freedom.

\section{Fear to depart from capitalist consumption}

Chris McCandless has tried to leave the materialist society he once lived in by having a trip to Alaska, where he could stay alone. He is signified as an immaterialist by donating all his money to charity and rejecting the new car that his family offered because money cannot buy his respect (Krakauer, 1995). He is also signified as a person who rejected the rules and all systems in it. This can be seen from the sequence when he did not follow the flash flood 
sign, burned the money, did not carry any ID, did not have a hunting license, and even he swore to government that "how I feed myself is none of governments business. Fuck their stupid rules" (Krakauer, 1995). He is also signified as a hater of his old society because he did not use his real name anymore when introducing himself. By considering these signifiers, his actions connote the rejection towards materialistic society and capitalism.

While McCandless' actions connote the rejection towards materialistic society and capitalism, it is found in the plot development that he had a persistent fear to depart from capitalist consumption such as he had worked in McDonald's by using his real name and he showed any lack of surviving skills. The sequences, which show that McCandless worked in McDonald's, are sequences $\mathbf{9 a}$ and $\mathbf{9 b}$ and the sequences which show that McCandless was lack of experience are sequences 16b and 17c. Sequence 9a tells about McCandless' job in McDonald's. McCandless applied for a job in McDonald's in Bullhead city. Sequence 16b tells about McCandless' problem concerning Teklanika River. In this sequence, McCandless had a really big problem in crossing the Teklanika River. The water was so deep and flew fast, while he was a weak swimmer and fear of water. This was the result of McCandless' inexperience especially in living inside the jungle. Sequence $17 \mathbf{c}$ is about the declaration after failing to process the carcass. In the sequence 17c, McCandless got a dead moose, but he seemed to find any difficulty in handling the meat.

The first evidence which reveals that McCandless has a persistent fear to depart from capitalist consumption is the fact that he had worked in McDonald's. This happens in sequence 9b which is about McDonalds' employee's thought on McCandless.

Curiously, when McCandless applied for the McDonald's job, he presented himself as Chris McCandless, not as Alex, and gave his employers his real Social Security number. It was an uncharacteristic break from his cover that might easily have alerted his parents to his whereabouts. (Krakauer, 1995:29).

The first line of the quote mentioned that McCandless had worked in McDonald's. Knowing that he had worked in McDonald's denies the idea of rejecting capitalism and materialism since McDonald's is considered as a symbol of capitalism. The fact that McCandless had worked in the restaurant proves that McCandless could not escape from capitalism. Working in a company means McCandless should follow the rule, including telling his true name. By following the rule seems contradictory with McCandless who rejected the rules and the systems in the society.

The first line of the quote above also mentions that he introduces himself as McCandless, not Alex. Working in the big company might require the true identity of the worker, so McCandless might give his ID card when he applied for the job. When he used 
Alex name, McCandless had thrown away his old life as Christopher Johnson McCandless. However, the fact that he used his true identity in applying for the job in McDonald's reveals that he could not be free from his old society. This contradiction shows any inconsistency towards McCandless' actions. His action might alert his parents about his location as mentioned in the quote above, but referring that he continued his trip afterward, he might just need the money that he got by working in McDonald's. Thus, in this state, McCandless realized that he could not survive his life and reach his destination just to rely on what he had found on the road. He still needed money before he reached Alaska to buy the tools to survive. Knowing that he still needed money signifies that he could not escape from capitalism because money is also a symbol of capitalism. This is how McCandless still had a fear to depart from capitalist consumption.

The second evidence is having a lack of experience to live in wildlife. The fact that McCandless had been raised in the upper-middle-class family cannot be hidden. Thus, he did not experience how to live in nature before he left his home. While he was in his journey, McCandless had learned from the local hunters about surviving skills and also from the book that he had in the University of Alaska about the edible plants. However, from the further investigations towards the plot development, McCandless had struggled in dealing with the moose meat. In processing the moose meat, McCandless had found any difficulty as shown in the part of the story below which happened in sequence $\mathbf{1 7} \mathbf{c}$.

Alaskan hunters know that the easiest way to preserve meat in the bush is to slice it into thin strips and then air-dry it on a makeshift rack. But McCandless, in his naivete, relied on the advice of hunters he'd consulted in South Dakota, who advised him to smoke his meat, not an easy task under the circumstances. "Butchering extremely difficult," (Krakauer, 1995:114)

The first line denotes the easiest way to preserve meat; instead, McCandless used the smoking method. McCandless did not know the easiest way to preserve the meat, so he followed the advice from South Dakota Hunter. Knowing the conditions where he was in South Dakota and Alaska was totally different, the method of preserving the meat is also different. Thus, this condition makes McCandless failed in the end to process the moose meat when the maggots started to appear. This also reveals that McCandless had no experience before in dealing with the big game because before he left his society, he used to eat the food he could find in his society, which was a capitalist society. Thus, this condition connotes that McCandless had any fear to depart from capitalist consumption. 


\section{Endless suffering from loneliness}

Chris McCandless has spent lots of his time alone. Not only when he left but also when was at home. His sister, Carine, also stated that he spent his time mostly alone in his family. In his trip to Alaska, he had met several people who were interested in him, but he decided not to stay for too long with them. In Anza Borrego, McCandless had met Ronald Franz who wanted to adopt him, but McCandless rejected his offer and then he claimed that he felt relieved to evade the emotional baggage resulted from the further relationship. When he met Stuckey in Alaska, McCandless claimed he wanted to spend his time alone in Alaska without any single person and any sign of civilization. He also declared his independence when he was in Alaska by mentioning about no longer to be poisoned by civilization (Krakauer,1995). Thus, this evidence signifies McCandless as a loner.

While he was depicted as a loner from the evidence above, further investigation found that there are several pieces of evidence which reject the idea of McCandless as a loner. Instead, this evidence signifies McCandless was suffering from endless loneliness. That evidence is reflected in sequence 13b where McCandless saw the clash of his parents so often; in sequences: $\mathbf{3 b}, \mathbf{6 b}, \mathbf{1 0 b}$, and $\mathbf{1 2 b}$ which show that McCandless was staying in touch with the people he met on his journey; and in the sequences 18a, 18b, and 19a which show that McCandless was lonely.

. In the sequence 13d, Carine said that their parents are only concerned about money. They rarely saw their parents at home because they were too busy working in the office. This was the reason McCandless left home. In the sequence 18a, McCandless decided to go back to civilization. He wanted to share his experience with the world. He intended to walk out. In sequence $\mathbf{1 8 b}$, McCandless had finished reading about family happiness. In the sequence, $\mathbf{3 b}$ McCandless stayed in touch with Westerberg by giving him one of Tolstoy's books and sending him a postcard every one month or two. In the sequence $\mathbf{6 b}$, McCandless was with Jan Burres and Bob. He camped with them for a week on Orick Beach. When he left them, he left the impression that he was a good person. McCandless always kept in touch with Jan Burres and Bob. In the sequence 10b, McCandless visited Burres and Bob at The Slab where lots of trampers and vagabonds gathered there. He had a good time with people and talked a lot to them. Lots of people were attached to him. In the sequence $\mathbf{1 2 b}$, Westerberg introduced McCandless to his mother, Mary Westerberg. The result is, Mary got pretty attached to McCandless and talked for hours with him. All these sequences show that McCandless was really sociable that he could talk with new people he met and get in touch with them. In 
sequence 19a, McCandless had torn a paper from Louis L'Amour's memoir and wrote a goodbye message.

One of the evidence which signifies loneliness characterization happens in sequence 13b. In sequence 13b, Carine McCandless mentioned that they rarely saw their parents home because they worked all the time (Krakauer, 1995). They often saw the clash between their parents that they often used verbal sparring and sometimes threatened divorce (Krakauer, 1995). His conditions back then were in a family who were so busy making money and were often in a clash. Having a family with lots of clashes causes McCandless feels a lack of happiness. There was no interaction between family members because the parents are only concerned about money. By knowing the fact that McCandless did not have lots of interaction with his parents and often to see the clash between his parents reveal that he was in a state of loneliness. Perlman \& Peplau (1981) mention the parents who were less trustworthy, disagreeable, and divorced cause great loneliness towards the children. McCandless had experienced that his parents were disagreeable, have lots of clashes, and almost got divorced. There was a different way of thinking between McCandless with his parents which cause disagreement. There were a lot of clashes happened between Walt and Billie which causes them almost got divorced. These facts cause great loneliness feeling inside his heart. He felt that his society was not warm anymore. Then, as a result, he decided to leave the society with the reason to find freedom.

The sequence $\mathbf{3 b}, \mathbf{6 b}, \mathbf{1 0 b}$, and $\mathbf{1 2 b}$ tell the moments when he met Westerberg in Carthage; Burres and Bob while he was picking berries and stayed with them for a week; and Ronald Franz in Anza Borrego. All these people mentioned that McCandless always got in touch to them and that the people around him are pretty attached to him. Westerberg mentioned that McCandless used to tell the people about amazing stories and lots of people in Carthage were attached to McCandless. When McCandless was with Burres at The Slab, Burres mentioned that McCandless had a really good time with people and he did a lot of socializing. When he was with Franz, Franz was so attached to McCandless that made him wanted to adopt McCandless as his grandson. This evidence signifies McCandless as a sociable person. The fact that McCandless loved to socialize with the people he met in his journey denies the idea of McCandless as a loner. This evidence proves that McCandless loved to socialize with people. He still loved to get along with people. This is in contrasts with his goal to live alone in Alaska.

The strong evidence of suffering from loneliness is when McCandless realized true happiness. The phrase "HAPPINESS ONLY REAL WHEN SHARE” (Krakauer, 1995: 129) 
shows that McCandless realized that true happiness is with people around him. This shows his regret because he threw away everything he got just to fulfill his ambition to get freedom from society. This also highlights that what McCandless wanted the most is happiness, not freedom. That is why he felt unhappy at the end of the story. McCandless was unhappy because he was in the state of loneliness. Perlman \& Peplau (1981) stated that in order to minimalize the feeling of loneliness, people can try to reduce their loneliness' feeling by gratifying their needs in alternative ways.

Referring to the above statement, McCandless was lonely. What McCandless needs the most was happiness. In order to find happiness, he used the journey to Alaska as the escape route to reduce his loneliness. As a sociable human being, his character shows that he was easy to get attached to people whom he met. He could impress those people and showed his respect towards them. Living alone would not bring him what he wanted from the bottom of his heart. He did not get experiences, he did not get warm feelings from the other people, he could not share his experience, he could not talk about philosophy, and more importantly, he did not find any happiness which he realized when he lived for months inside the magic Bus 142 in Alaska. He did not find any happiness in his old society which only concerned about money because he thought that money could not buy his respect. If it is referred to what Pearlman and Peplau have stated, McCandless was lonely after all. In order to reduce his loneliness, he is gratifying what he wanted the most, which was happiness, by having a trip to Alaska.

\section{CONCLUSION}

Based on the result, the depiction of Chris McCandless as a freedom chaser is denied through the evidence found during further investigation towards the plot development of Into The Wild. As a person who sought an adventure in nature, McCandless would deal with water, but knowing that he had fear of water, it is contradictive with his characterization as an adventurer. As a person who rejected capitalism and materialist society, he was found working at McDonald's to earn some money in which both McDonalds and money are symbols of capitalism and materialistic society. As a person who spent his time mostly alone and intended to be alone in Alaska, he was a lonely person after all. Thus these contradictions demystify the myth of freedom that McCandless chases.

After meeting with warm people during his journey, McCandless seems realized that what he intended to find is not freedom, but happiness from the people around him. He did not get that happy when he was in his old society in which his parents only concerned with 
money and often had a clash. He was lonely from the beginning. After he met the warm people in his journey, and he left them to stay alone in the jungle, he seems realized that he was lonely in the end. This endless suffering from loneliness covers McCandless from the beginning and at the end of his life. The society that he missed was the kind of society that he met during his journey and the society that he hated was the society that he was once before his journey to Alaska. Therefore, he left that society to chase what he believed as freedom, which is just a myth.

\section{REFERENCE}

Barthes, R., \& Lavers, A. (1972). Mythologies. London. Hill and Wang.

Bouzida, F. (2014). the Semiology Analysis in Media Studies - Roland Barthes Approach. Socioint14: International Conference on Social Sciences and Humanities, (September), 1000-1006.

Cobley, P., \& Jansz, L. (n.d.). Introducing semiotics. McPherson's Printing Group Victoria

Given, L. M. (2008). The Sage encyclopedia of qualitative research methods. Sage Publications.

Hayek, F. A. von (Friedrich A. (2006). Constitution of liberty. Routledge.

Krakauer, J. (1995). Into the wild. Macmillan.

Perlman, D., \& Peplau, L. (1981). Toward a social psychology of loneliness. Personal Relationships, (6), 31-55. https://doi.org/10.1037/0003-066X.41.2.229

Prior, L. (2008). Document analysis. The Sage Encyclopedia of Qualitative Research Methods. https://doi.org/10.4135/9781412963909

Sebeok, T. A. (Thomas A. (1994). Signs : an introduction to semiotics. University of Toronto Press.

Stanford University., \& Center for the Study of Language and Information (U.S.). (1997). Stanford encyclopedia of philosophy. Stanford University. Retrieved from https://plato.stanford.edu/entries/liberty-positive-negative/ 